\title{
Ecosystem health subject of landmark gathering
}

$\mathrm{T}$ he first gathering of its kind in the United States, the International Congress on Ecosystem Health will bring together more than 1,500 researchers, policy-makers, conservationists, industry representatives and others from around the world to Sacramento Aug. 15 to 19 , for a grand discussion on the management of complex ecosystems to conserve the integrity of natural resources and environmental health.

"This topic will determine the future quality of life on this planet, because we're responsible for the present conditions and capable of determining the future conditions," says Bill Lasley of the UC Davis School of Veterinary Medicine, co-convener of the Congress with David Rapport, president of the International Society for Ecosystem Health. "We need to share and assimilate ideas, and find some common ground."

More than 200 presenters will focus on preventing, diagnosing and predicting global and regional environmental problems. "The Congress is a forum for anyone who needs to hear what's on the minds of the more visible thinkers in this area," Lasley says. "It's an opportunity to think and plan for the future."

The fundamental ecosystem questions for agriculture, Lasley says, are: "How has farming affected the environment? And how can farming be changed?" Because more ground space is involved in farming than in any other industry, agricultural research is shifting its focus from "harvesting, producing and extracting to longterm management," he adds.

The Congress is organized and hosted by UC Davis, the office of the UC Vice President for Agriculture and Natural Resources, and the International Society for Ecosystem Health. It builds on the work of the first symposium on ecosystem health in Ottawa, Canada in 1994, and a second symposium in Copenhagen in 1996.

Scheduled keynote speakers include Kenneth Olden, director of the U.S. National Institute of Environmental Health Sciences and the $\mathrm{Na}$ tional Toxicology Program; Ambassador Ola Ullsten, former prime minister of Sweden; Robert $\mathrm{T}$. Watson, director for environment at the World Bank; Douglas Wheeler, former Califor- nia secretary of resources; and science writer Laurie Garrett, author of The Coming Plague.

In addition to more than 40 technical workshops, scientific field trips will be offered to nearby sustainable agriculture operations and wetlands, the San Francisco Bay, Lake Tahoe, Clear Lake, Monterey Bay, and the Napa and Sonoma wine regions.

Finally, 14 discussion forums will develop recommendations for future use by policy-makers, scientists and environmental organizations.

\section{Agriculture and human health}

A number of technical sessions will be of interest to the agricultural community. For example, a symposium chaired by Marc Schenker of the UC Davis School of Medicine will juxtapose the ecosystem effects of agriculture on air, water and soil with human-health vectors such as pesticides, agricultural chemicals and infectious pathogens.

As agricultural practices have grown more intense, there has been a commensurate rise in impacts on ecosystems and human health, says Schenker, director of the UC Agricultural Health and Safety Center (AHSC) at Davis.

The scheduled speakers include Paul Gunderson, director of the Marshfield Medical Research Foundation in Wisconsin; Robert Flocchini, director of the Crocker Nuclear Laboratory at UC Davis; and Michael O'Malley, associate clinical professor at the UC Davis School of Medicine.

Dean Cliver of UC Davis will also discuss proposed research into the impacts of infectious disease agents in manure on agricultural field
Native grasses and plants are restoring the riparian ecosystem along a canal at Hedgerow Farms in Winters. Grower John Anderson will discuss "agroecology" during the upcoming ecosystem congress. 
